\title{
HUMAN RESOURCE PRACTICES AND PERFORMANCE IN SMALL SPANISH WINERIES, AND THEIR EVOLUTION WITH AGE AND SIZE
}

\section{PRÁTICAS E DESEMPENHO DE RECURSOS HUMANOS EM PEQUENAS ADEGAS ESPANHOLAS, E A SUA EVOLUÇÃO COM A IDADE E A DIMENSÃO}

\author{
Juan R. Ferrer ${ }^{1 *}$, Silvia Abella-Garcés ${ }^{2}$, María T. Maza-Rubio ${ }^{3}$ \\ ${ }^{1}$ Universidad Politécnica de Madrid, Escuela Técnica Superior de Ingeniería Agronómica, Alimentaria y de Biosistemas, Dept. Economía Agraria, \\ Estadística y Gestión de Empresas, Campus Ciudad Universitaria, Av. Puerta de Hierro, nº 2-4, 28040 Madrid, Spain. \\ ${ }^{2}$ Universidad de Zaragoza, Facultad de Empresa y Gestión Pública, Dept. Dirección y Organización de Empresas, Plaza de la Constitución s/n, \\ 22001 Huesca, Spain. \\ ${ }^{3}$ Universidad de Zaragoza, Facultad de Veterinaria, Dept. Ciencias Agrarias y del Medio Natural, Instituto Agroalimentario de Aragón-IA2 \\ (Universidad de Zaragoza-IA2), C/ Miguel Servet, 177, 50013 Zaragoza, Spain. \\ * Corresponding author: Tel.: +34 910670742, e-mail: juanramon.ferrer@upm.es
}

(Received 24.06.2020. Accepted 31.08.2020)

\section{SUMMARY}

This research aims to cover the existing gap in knowledge regarding human resource management practices in winery businesses. Three of the most important practices in this field - recruitment and selection, training and development, and remuneration - and their relationship with performance in small family and non-family wineries as well as the differences in those businesses' behaviours according to their age and size were analysed. The analysis was based on a 2016 database containing 339 Spanish wine sector SMEs, and a multivariate Bayesian regression methodology was applied. The results demonstrate a lower level of human resource management practices in small family businesses and a stronger relationship with performance than in non-family businesses. The results also show that human resource management varies according to the age and size of the company, indicating an inverted U-shaped relationship with size. On the one hand, these results highlight the importance of human resource practices in the environment of a small winery. These practices have not usually been considered as drivers of performance in small family firms. On the other hand, the results can be useful for the managers of such firms, both in the wine industry and in general, as they highlight the human resource practices that could improve the performance of those entities. The paper contributes to filling the existing gap in the literature related to small family businesses.

\section{RESUMO}

Esta pesquisa visa cobrir a lacuna existente no conhecimento sobre práticas de gestão de recursos humanos em empresas vinícolas. Foram analisadas três das práticas mais importantes neste campo - recrutamento e seleção, treino e desenvolvimento, e remuneração - e sua relação com o desempenho em pequenas adegas, familiares e não familiares, bem como as diferenças no comportamento dessas empresas de acordo com a sua idade e a sua dimensão. A análise foi baseada num banco de dados de 2016 contendo 339 PME do setor vinícola espanhol, tendo sido aplicada a metodologia de regressão bayesiana multivariada. Os resultados demonstram um nível mais baixo de práticas de gestão de recursos humanos em pequenas empresas familiares e uma relação mais forte com o desempenho do que em empresas não familiares. Relatam também que a gestão de recursos humanos varia de acordo com a idade e a dimensão da empresa, encontrando uma relação em U invertido com a dimensão. Por um lado, estes resultados destacam a importância das práticas de recursos humanos no ambiente de uma pequena adega. Estas práticas não têm sido geralmente consideradas como motores de desempenho em pequenas empresas familiares. Por outro lado, os resultados podem ser úteis para os gerentes de tais empresas, tanto na indústria do vinho como na indústria em geral, pois destacam as práticas de recursos humanos que podem melhorar o desempenho dessas entidades. $\mathrm{O}$ artigo contribui para preencher a lacuna existente na literatura relativamente às pequenas empresas familiares.

Key words: Wine industry, age, performance, small family business, HRM practices.

Palavras-chave: Indústria do vinho, idade, desempenho, pequenas empresas familiares, práticas de gestão de recursos humanos.

This is an Open Access article distributed under the terms of the Creative Commons Attribution License (https://creativecommons.org/licenses/by/4.0), which permits unrestricted use, distribution, and reproduction in any medium, provided the original work is properly cited. 


\section{INTRODUCTION}

The Spanish wine sector has certain properties that make it especially interesting. It is one of the oldest industries, it is rooted in Mediterranean traditions, it accounts for a highly important part of agricultural production, and it enables the fight against depopulation and the favouring of environmental equilibrium. Moreover, the Spanish wine industry is facing important challenges, such as the end of the Common Market Organization (CMO) in 2020, society's increasing pressure on the sector to become environmentally sustainable, climate change, the consolidation of supply from New World countries, the decrease in wine consumption in Spain as also in Europe, and the increase in international commerce and industry competition (Bardaji and Iraizoz, 2015; Ashenfelter and Storchmann, 2016; Resco et al., 2016; García-Cortijo et al., 2019).

The wine industry in Spain in 2015 accounted for 8.241 million euros in terms of production and 3,709 firms that employed 24,413 people (INE, 2018). These firms are mainly small businesses. Small businesses account for more than $99 \%$ of the total number of businesses and $37.6 \%$ of the total value added in Europe-28 (Eurostat, 2019). Furthermore, in the case of wine firms, according to FerrerLorenzo (2018), 97.6\% of the firms are small businesses (comprising fewer than 50 employees).

It is also of importance that in the case of Spain, $88.8 \%$ of the businesses are family businesses (FBs), which generate $66.7 \%$ of the employment and $57.1 \%$ of the gross domestic product (GDP). Also, 90.3\% of all Spanish small businesses are FBs (IEF, 2019). Family businesses account for approximately $60 \%$ of the Spanish wine sector, considering a firm to be a FB if the family owns more than $50 \%$ of the company (Soler et al., 2017), which is an even greater percentage than in the Italian and French wine sectors, in which they are reported to account for less than 50\% (Bresciani et al., 2016). This high number of FBs is related to the fact that the wine industry is closely connected to tradition, culture, values, and property (Gallucci et al., 2015).

The specificity of the resources of a given family firm is defined as 'familiness' and is 'the unique bundle of resources a particular firm has because of the systems interaction between the family, its individual members, and the business' (Habbershon and Williams, 1999), with 'human capital' being one of the most important resources (Sirmon and Hitt, 2003). Human capital includes the knowledge, skills, and abilities of employees (Sirmon and Hitt, 2003; Dyer, 2006). Despite the importance of people in
FBs, as the core of one of the most important and explanatory resources because of their competitive advantage, consensus exists among researchers that human resource management (HRM) in companies has been only scarcely and partially studied in prior research (Astrachan and Kolenko, 1994; De Kok et al., 2006; Dawson, 2012; Pittino et al., 2016; Sánchez Marín et al., 2017; Steijvers et al., 2017).

However, the problem is not only that empirical studies analysing HRM in FBs are scarce (Steijvers et al., 2017); the important issue is also that most of these studies are fragmented and reach somewhat confusing conclusions about human resources in FBs (Pittino et al., 2016). Moreover, the conclusions are sometimes contradictory when evaluating the importance of HRM practices in those types of businesses (Sánchez Marín et al., 2017). It is important to point out that the scarcity of studies is even more evident for smaller firms, namely companies with fewer than 50 employees (Sánchez Marín et al., 2017), and studies that analyse the evolution of those firms according to the age of the company are also limited in number (Gnan and Lambrechts, 2018). The scarcity of studies on HRM in the wine sector is also much more noticeable than in other sectors. Only two studies were found; one is based on the Australian wine sector (Kidwell and Fish, 2007), and the other compares the Australian and the US industries (Thach and Kidwell, 2009).

Therefore, it is evident that there is a significant lack of knowledge, as well as contradictory results, regarding whether HRM practices are related to performance as a whole. This situation is much more critical with regard to small business, where there are few studies on HRM and how HRM practices evolve with the age and size of the company. In this paper, three of the most relevant HRM practices identified by scholars - selection, training, and remuneration (Cardon and Stevens, 2004; De Kok et al., 2006; Sánchez-Marín et al., 2017) - were analysed. The study investigates whether the level of use of these practices is lower in small FBs (SFBs) than in small non-family ones, and it explores the relationship that exists between these practices and performance. Likewise, the use of these practices is examined based on the age and size of the company.

\section{MATERIAL AND METHODS}

\section{HRM practices in FBs}

Human resource management is defined as the process of attracting, developing, and maintaining a talented and energetic workforce to support the organisational mission, objectives, and strategies 
(Carrasco-Hernández and Sánchez-Marín, 2014). The development of HRM is fundamental for SFBs, since an individual's behaviour and the unique characteristics of employees' knowledge create a 'human capital advantage' (Boxall, 1996), and they are the base for the formulation and implementation of the company's strategy and performance (Dawson, 2012). Companies must develop HRM practices to have employees with the skills and knowledge necessary to perform their duties both when they join the company and for the duration of their employment there, because any human capital advantage may decrease in the long term (LópezCabrales et al., 2009). SFBs located in rapidly changing environments are forced to continue adapting and expanding the techniques and knowledge of their employees; otherwise they may lose their competitive advantage (De Kok et al., 2006; Lozano-Reina and Sánchez-Marín, 2019). HRM practices explain the managerial process that allows for the alignment of employees' knowledge and skills with the strategy of the firm and its higher performance (López-Cabrales et al., 2009).

Given the duality of the objectives in SFBs, the greater the value created for the family, the greater the value created for the company (Gómez-Mejía et al., 2007; Dawson, 2012); this means that typical HRM practices are not encouraged in these firms and that, when they are, they are complemented with actions with greater emotional links, such as altruism and nepotism (Schulze and Gedajlovic, 2010). Therefore, nepotism, which favours family members over non-family members, becomes a demotivation factor for non-family employees (Barnett and Kellermans, 2006; Dawson, 2012). As a consequence, FBs lay aside one of the most important HRM practices: personnel selection (Barnett and Kellermans, 2006; Dawson, 2012; Boxall, 2013). Family businesses do not recruit the most suitable person for a position (Dyer, 2006; Gómez-Mejía et al., 2011; De Massis et al., 2015), and they do not develop personnel selection departments managed by clear and transparent objectives, thus making it difficult to recruit people from outside the family (Gómez-Mejía et al., 2011; Carrasco-Hernández and Sánchez-Marín, 2014). This is the first disregarding element of one of the crucial practices of HRM (Barnett and Kellermanns, 2006); FBs start with a disadvantage, compared to non-family businesses (NFBs), because of the lack of an adequate recruitment and selection mechanism, which in turn results in the hiring of people who are not the most appropriate fit (Gómez-Mejía et al., 2011).
Training practices improve employees' technical abilities to solve problems, allow for the generation of new understanding and new ideas, improve productivity, and lead to a competitive advantage and hence sustainable performance (Kotey and Folker, 2007; López-Cabrales et al., 2009). Employee development practices include career management, mentoring, and coaching, and they promote the enhancement of employee skills in order to improve the performance of the company (Cosh et al., 1998; López-Cabrales et al., 2009).

However, investments in employee training and development are lower in FBs than in NFBs (Reid and Adams, 2001). Moreover, such training tends to be more unstructured in FBs and almost always avoids the field of management, implying that family entrepreneurs distrust the training of their employees in those skills (Kotey and Folker, 2007). Furthermore, since companies must be efficient to create maximum value in the current competitive environment, they have a need for employees who are engaged and who possess the knowledge and skills necessary to perform their functions (CarrascoHernández and Sánchez-Marín, 2014), and this is linked to training and development programmes, which occur less on average in FBs than in NFBs (Reid and Adams, 2001; Kotey and Folker, 2007).

The third analysed element is the remuneration policy. Remuneration refers to the consideration received by an employee as a reward for his or her work in a company. It consists of three components: 1) the base salary or fixed amount that an employee receives regularly; 2) incentive salaries or rewards received for the achievement of certain objectives; 3 ) benefits or indirect remuneration, which cover a wide variety of programmes (Carrasco-Hernández and Sánchez-Marín, 2007). Remuneration is an element of motivation and of alignment of the employee's interests with the company's objectives, reducing agency costs and practices such as egoism, selfishness, or laziness (Gerhart and Milkovich, 1992). In this regard, two effects take place in FBs: on the one hand, there is the willingness of the employees belonging to the family to make certain remuneration waivers and to accept lower wages in exchange for a secure future (Sciascia and Mazzola, 2008) or the knowledge that their position is not subject to reduction plans (Schulze and Gedajlovic, 2010); on the other hand, there is the emotional reward that employees receive (Gómez-Mejia et al., 2011), through their family membership, from the altruistic spirit of the management. The existence of these important elements of emotional remuneration means that monetary rewards are lower in FBs, where loyalty rather than performance is rewarded through 
social-emotional ties (Sciascia and Mazzola, 2008). The lower remuneration level also extends to CEOs, who receive less compensation in FBs than in NFBs (Gómez-Mejía et al., 2003). Moreover, they also receive smaller amounts of variable wages (CarrascoHernández and Sánchez-Marín, 2007; Sánchez-Marín et al., 2017). Compensation is linked to permanence and loyalty, without considering performance bonuses (Sánchez-Marín et al., 2017). This lower level of compensatory elements and motivators will cause a lower yield (Dawson, 2012), although the possible loss of motivation is intended to be recovered with the profusion of emotional ties (De Kok et al., 2006).

The HRM practices in FBs favour the best effort of the employees, which is confirmed by a better performance (Astrachan and Kolenko, 1994; De Massis et al., 2015), and the achievement of a competitive advantage (Brandenburger and Stuart, 1996; Besanko et al., 2009). In this study, three of the HRM practices that have been considered to be the most relevant ones in previous studies are analysed-recruitment and selection, training and development, and remuneration (Astrachan and Kolenko, 1994; De Kok et al., 2006; CarrascoHernández and Sánchez-Marín, 2014; Pittino et al., 2016). Previous studies have looked at the relationship of HRM practices with the achievement of better performance. The disadvantage in the performance that supposes a deficit of recruitment and selection practices is indicated by Astrachan and Kolenko (1994), Carrasco-Hernández and SánchezMarín (2014), Pittino et al. (2016), and Steijvers et al. (2017). Regarding training and development practices, their relationship with performance is pointed out by Cosh et al. (1998), Kotey and Folker (2007), and Carrasco-Hernández and Sánchez-Marín (2014), who argue that companies need to be efficient and competitive, and firms thus need to have employees with certain knowledge and skills to develop their functions. Thirdly, the positive relationship between remuneration practices, as an element of motivation and alignment, and better performance is confirmed by Astrachan and Kolenko (1994), Dawson (2012), Carrasco-Hernández and Sánchez-Marín (2014), and Sánchez-Marín et al. (2017), among others.

\section{HRM practices in FBs and the age of a company}

As pointed out above, little research exists on HRM practices in FBs (Dawson, 2012; Pittino et al., 2016), and it is even more difficult to find references concerning how they evolve with age. LeónGuerrero et al. (1998) argue that HRM practices, such as written job descriptions, incentive compensation, and formal employee reviews, increase as growth and development take place. However, confined to FBs, no references were found to HRM's evolution with age; the references to age are mainly focused on the analysis of efficiency and management. Anderson and Reeb (2003) and Miller et al. (2007) maintain that when the governing of a business passes to the founder's descendants, the company loses efficiency and productivity, and Mazzi (2011) states that young FBs are more efficient and better managed. Over time, the positive effect of the family diminishes (González et al., 2012) at the rate at which the family loses control of the company (Franks et al., 2011), worsening when, as a result of nepotism, the company does not appoint a qualified external manager (Martínez and Requejo, 2017). As the age increases, the objectives of efficiency and results are diluted, and they give way to socio-emotional and succession objectives. Although there are conflicting opinions, Aldrich and Auster (1986) argue that being very young or very old is not ideal for FBs. Others think otherwise: after a succession crisis period, companies recover their efficiency, small and old companies achieve better performance (Miralles-Marcelo et al., 2014), and age can have a positive effect on performance, at least in technological industries, if there is a change in the CEO. Age favours the implementation of routines and the recognition of technological opportunities (Cucculelli et al., 2014). However, Poutziouris et al. (2015) are more emphatic when they state that efficiency is inversely related to age and that FBs are more efficient the younger they are. Since the inertia of years negatively affects FBs by producing a tendency to ignore market signals, a culture that makes organisations inflexible, resistant to change, and preoccupied with maintaining family traditions prevails (Cucculelli et al., 2014).

\section{HRM practices in FBs and the size of a company}

Age and size are two differentiated elements, and they do not have to be correlated or condition the business practices of HRM in the same way (Cardon and Stevens, 2004). The decision to grow in size is part of the strategic options for the development of a company; however, this is not the case for aging, which is intrinsically linked to the business's historical development. As the company grows in size, it is more likely to develop HRM practices (Kotey and Folker, 2007; Rauch and Hatak, 2016). When the company increases its size, it professionalizes its functions and can dedicate specific resources to HRM (Markman and Baron, 2003) with regard to recruitment and the selection of personnel (Bayo-Moriones and Merino-Díaz, 2001), training and development (Bayo-Moriones and Merino-Díaz, 2001; Kotey and Folker, 2007), and 
remuneration practices (Bayo-Moriones and MerinoDíaz, 2001). By contrast, small or very small companies are not able to dedicate resources to those functions, which are assumed by the company's management team members, who are not HRM professionals (Bayo-Moriones and Merino-Diaz, 2001; Cardon and Stevens, 2004; Patel and Cardon, 2010), and who must share these functions with the management of the firm. This hinders the deployment and development of those companies, thereby causing them to achieve a more limited evolution (Markman and Baron, 2003; Patel and Cardon, 2010). However, the way in which HRM practices evolve with the increase in company size is not as evident, with its rate of growth increasing rapidly at the beginning and slowing down later (Kotey and Folker, 2007). This lower growth may be the consequence of the appearance of bureaucratization in the company, driving HRM practices to be less agile, which in turn results in disaffection amongst certain workers (BayoMoriones and Merino-Díaz, 2001).

Thus, the following hypotheses are proposed:

Hypothesis 1: Small family businesses (SFBs) use human resource management (HRM) to a lesser extent than small non-family businesses (SNFBs).

H1a: SFBs use recruitment and selection practices to a lesser extent than SNFBs.

H1b: SFBs use training and development plans to a lesser extent than SNFBs.

H1c: Remuneration levels in SFBs are lower than those in SNFBs.

Hypothesis 2: Recruitment and selection, training and development plans, and remuneration are positively related to performance.

Hypothesis 3: SFBs have a different level of HRM practices depending on the age of the company.

Hypothesis 4: SFBs increase the level of HRM practices as they grow in size.

\section{Sample}

The study relies on two databases to define the sample of companies operating in the Spanish wine sector. The first database consists of registries of protected designations of origin (PDOs). The second is the 'Sistema de Análisis de Balances Ibéricos' (SABI, 2017), from which companies that were registered as 'wine companies' and were active in 2015 under title 11.02 of the National Classification of Economic Activities (CNAE, which corresponds exactly to the European coding system NACE) were selected. The final sample consisted of 3,286 entities. Following previous studies (Spanos and Lioukas, 2001), records with missing data, companies with no valid telephone number or email address, companies without a firm structure, and those that existed only as subsidiaries of another wine company, were eliminated.

As a result of this process, the number of independent companies was reduced to 2,413 . The survey was sent via email to general managers, marketing managers, and/or production managers, with a telephone reminder issued one month later. The process took place from February to May 2016, and the requested information applied to the end of the previous year (December 2015). At the end of the process, a total of 339 valid responses were received, representing $14 \%$ of the total sample; this is a valid percentage for industrial sectors (Baruch and Holtom, 2008). The confidence level is 95\%, and the sample error is $4.9 \%$.

In this study, a business is considered to be an SFB when the company defines itself as a family, the family owns more than $50 \%$ of the business, family members are involved in management (Maury, 2006; Lindow et al., 2010; Sánchez-Marín et al., 2017), and the company size is fewer than 50 employees. Finally, 267 companies of the 339 valid responses met the requisites of the definition. These 267 companies were analysed using the SABI database to determine the link between owners and management boards. It was found that 120 out of those 267 companies have family members involved in management; therefore, according to our definition, they are FBs, whereas 147 are NFBs.

From the business model point of view, the SFBs in the wine sector $(45.3 \%$ of the total sample) are at the end of the value chain, close to the distributor and the final customer, since they produce $21.1 \%$ of the wine but bottle $58.61 \%$ of the national total wine production (OEMV, 2017). This element might be related to the concept of family, culture, name, tradition, and its use in the development of the prestige of the product offered (Gallucci et al., 2015).

\section{Variables}

The survey was configured after an extensive literature review. The questions and scales used have been validated in previous studies, analysing resources and capabilities as well as performance. In addition, to justify the survey's applicability to the Spanish wine sector, a subsequent validation among firms, experts, and managers within the Spanish wine sector was conducted. The objective was to 
ensure that the survey was understandable and that it reflected the peculiarities of the industry.

\section{HRM practices}

Three indicators were used to evaluate the HRM practices, each with a five-point Likert scale on which the firm marked its position, relative to its competitors, from 1 ('much weaker than competitors') to 5 ('much stronger than competitors'). The questions were adapted from Rubio-Bañón and Aragón (2008) and CarrascoHernández and Sánchez-Marín (2014). The study measured 1) staff recruitment and selection, 2) occupational training and development, and 3) remuneration systems.

\section{Control variables}

Numerous studies have referred to the influence of elements, such as company age, size and export orientation, on performance. For this reason, the majority of studies have incorporated control variables to further elucidate business performance (Gómez-Mejía et al., 2007; Kotlar et al., 2013). In this study, three control variables were used: age, size, and export orientation. Age was measured as the years of life of the company, and company size was based on assets, with seven categories spanning values from less than 400,000 to more than 40 million euros.

The third control variable is export orientation, as it is reported to be related to performance, since only companies that are more productive are able to export and, by controlling their costs, open new markets (Chaney, 2008). Companies in the wine sector in Spain have doubled their presence in the international market in recent years, with continuous growth of their exports (Fernández and Pinilla, 2018). Exporting in the wine sector is referred to as the business model that is most related to performance (Serrano et al., 2018; Ferrer-Lorenzo et al., 2019).

The variable was measured through a scale consisting of seven categories, where export orientation was measured from 1 ('does not export') to 7 ('exports more than 75\%').

\section{Business performance}

This study aims to analyse business performance similarly to Spanos and Lioukas (2001), Ortega (2010), or Ferrer-Lorenzo et al. (2018), assessing two dimensions -market and financial performance with respect to the last three years of a firm's business activity. The first dimension evaluates a company's external performance, measured by its market behaviour in terms of its 1) sales volume in euros, 2) sales volume growth in euros, 3) market share as a percentage of sales in euros, and 4) growth of the market share in sales in euros. The second dimension focuses on the company's internal performance - the income generated by its economic activity (Spanos and Lioukas, 2001) - based on its profit margin, return on its own capital, and net profit. Using a five-point Likert scale, companies evaluated their position in relation to their competition from 1 ('well below average') to 5 ('well above average'). In this study, subjective scales to ascertain business performance were used. As accounting data can be subject to annual variability and may include extraordinary results and changes outside the company's main activity, several studies confirm the confluence of subjective and objective scales (Dess and Davis, 1985; Richard et al., 2009; Santos and Brito, 2012), and these are used in numerous empirical studies (Spanos and Lioukas, 2001; Ortega, 2010; Ferrer-Lorenzo et al., 2018). To ensure that self-reported performance measures have statistical validity, the correlation between these self-reported performance measures and the performance measures (rate of return and return on investment) obtained from the SABI database was calculated. The correlations suggest significant and positive values with self-reported performance measures and both secondary sources of performance. Therefore, the hypothesis of independence between the variables is rejected at a 95\% significant level (Ortega, 2010).

\section{Methodology}

To test the proposed hypotheses, the Mann-Whitney $\mathrm{U}$ test was firstly used for independent and nonparametric samples to test for differences between SFBs and SNFBs. Second, to identify the relationship between HRM practices and competitive advantage, two Bayesian regression models were estimated: one for SFBs and another for SNFBs. Finally, the evolution of HRM practices with the age and size of the SFBs was analysed using three Bayesian multivariable regressions, where the independent variables are the three HRM practices studied: 1) recruiting and selection, 2) training and development, and 3) remuneration. In this case, the independent variables are age, assets, and export orientation. Age is measured with the $\log$ of the age and the $\log ^{2}$ to determine the shape of the function. The procedure was the same for the size variable (assets), in which the size and size ${ }^{2}$ were used.

\section{RESULTS AND DISCUSSION}

The results are presented in the same order as the explanation of the methodology used: first, the Mann-Whitney U test for the study of the differences 
between small FBs and NFBs, followed by the Bayesian regression to analyse the relationship between variables and performance, and finally the analysis of the use of HRM practices with the age and size of SFBs.

\section{Mann-Whitney U test}

Table I lists the values of the mean of the variables and their standard deviation for SFBs (column 2) and SNFBs (column 3) and the result of the MannWhitney U test (column 4). Columns 5 onwards list the Spearman correlation matrix. The results of Table I only indicate a statistically significant and differential value for one of the three HRM practices analysed for SFBs and SNFBs, namely 'staff recruitment and selection', which is lower for SFBs. For the other HRM practices, no statistically significant difference was found between groups, which leads to accept $\mathrm{H} 1 \mathrm{a}$ and reject $\mathrm{H} 1 \mathrm{~b}$ and $\mathrm{H} 1 \mathrm{c}$.

Table I

Mann-Whitney U test and Spearman's correlation

Teste U de Mann-Whitney e correlação de Spearman

\begin{tabular}{|c|c|c|c|c|c|c|c|c|c|c|}
\hline & \multirow{2}{*}{$\begin{array}{c}\text { SFB } \\
(2)\end{array}$} & \multirow{2}{*}{$\begin{array}{c}\text { SNFB } \\
(3)\end{array}$} & \multirow{2}{*}{$\begin{array}{c}\text { Mann- } \\
\text { Whitney } \\
\text { U test } \\
\text { (4) }\end{array}$} & \multicolumn{7}{|c|}{ Spearman's matrix correlation (5) } \\
\hline & & & & 1 & 2 & 3 & 4 & 5 & 6 & 7 \\
\hline $\begin{array}{l}\text { Staff recruitment and } \\
\text { selection (1) }\end{array}$ & $\begin{array}{l}2.79 \\
(0.71)\end{array}$ & $\begin{array}{l}3.08 \\
(0.85)\end{array}$ & $0.010^{* *}$ & 1 & & & & & & \\
\hline $\begin{array}{l}\text { Occupational training } \\
\text { and development (2) }\end{array}$ & $\begin{array}{l}3.06 \\
(0.70)\end{array}$ & $\begin{array}{c}3.21 \\
(0.84)\end{array}$ & 0.210 & $0.54 * *$ & 1 & & & & & \\
\hline $\begin{array}{l}\text { Remuneration } \\
\text { systems (3) }\end{array}$ & $\begin{array}{c}2.94 \\
(0.70)\end{array}$ & $\begin{array}{c}2.86 \\
(0.80)\end{array}$ & 0.263 & $0.53 * *$ & $0.52 * *$ & 1 & & & & \\
\hline Age (4) & $\begin{array}{c}31.66 \\
(35.66)\end{array}$ & $\begin{array}{c}34.73 \\
(29.90)\end{array}$ & 0.258 & -0.013 & -0.09 & -0.018 & 1 & & & \\
\hline Exports (5) & $\begin{array}{c}3.32 \\
(1.66)\end{array}$ & $\begin{array}{c}3.22 \\
(1.69)\end{array}$ & 0.594 & 0.10 & $0.14 * *$ & $0.18^{* *}$ & 0.003 & 1 & & \\
\hline Assets (6) & $\begin{array}{c}2.43 \\
(1.16)\end{array}$ & $\begin{array}{c}2.24 \\
(1.17)\end{array}$ & 0.145 & 0.11 & $0.14^{*}$ & $0.12 * *$ & $0.27 * *$ & $0.31 * *$ & 1 & \\
\hline Performance (7) & $\begin{array}{c}2.80 \\
(0.83)\end{array}$ & $\begin{array}{c}2.95 \\
(0.73)\end{array}$ & 0.239 & $0.32 * *$ & $0.24 * *$ & $0.36^{* *}$ & $0.19 * *$ & $0.19 * *$ & $0.35^{* *}$ & 1 \\
\hline
\end{tabular}

This fact has been pointed out, in a generalised manner, in previous empirical and theoretical studies, which attribute this result to the practice of nepotism in FBs - an element linked to their own existential principles (Dawson, 2012) - and it has been endorsed in this study. Regarding training and development practices, a statistically significant relation to suggest that SFBs have a lower endowment of this resource was not found, although its average values are lower than those for SNFBs. This conclusion is in direct contrast to the postulates of Kotey and Folker (2007), which imply a worse position in FBs. However, it ratifies the conclusions of Sánchez Marín et al. (2017), who find no difference between the two types of companies. The results regarding a company's remuneration policy are contrary to the hypothesis, revealing an equal if not superior situation in SFBs in comparison with
SNFBs; therefore, it cannot be concluded that a worse statistically significant situation exists in SFBs. This confirms the previous work of Sánchez Marín et al. (2017) and refutes the assumption that employees receive worse rewards in SFBs than in SNFBs, since FB employees are compensated with emotional bonds (Sciascia and Mazzola, 2008).

On the other hand, it is also apparent in the results of Table I that no statistically significant difference exists with respect to the control variables: age, export activity, and size.

\section{HRM practices in SFBs and performance}

A Bayesian regression, where performance was the dependent variable, was carried out. The results, differentiating between SFBs and SNFBs, are presented in Table II. 
Regarding SFBs and SNFBs, the results demonstrate that 'staff recruitment and selection' and 'remuneration systems' are positively related to performance $(99 \%$ in SFBs, and between $96 \%$ and $91 \%$ in SNFBs). The study presents a negative value in SFBs between performance and 'occupational training and development' ( $5 \%$ likelihood of positive impact), and without statistical significance in the case of SNFBs. For this reason, H2 is only partially corroborated. With regard to the control variables, as expected both in SFBs and SNFBs, assets are also related to performance $(99.9 \%)$. There is no relationship between export orientation and performance in SFBs (64.4\%); however, there is a strong relationship in SNFBs (98\%). No relationship was found between age and performance in SFBs and SNFBs. This peculiar situation of training and development is highlighted in earlier FB research by Sánchez-Marín et al. (2017), although, in their study, this negative sign for FBs did not reach statistical significance. The positive signs of recruitment and selection, which form the most relevant HRM practice, as well as of remuneration, are in line with most of the studies conducted since Astrachan and Kolenko (1994), and are not incompatible with other studies that consider a lower level of this practice in FBs.

Table II

Bayesian regression for SFBs and SNFBs, performance

Regressão bayesiana para SFBs e SNFBs, desempenho

\begin{tabular}{|c|c|c|c|c|c|c|c|}
\hline \multirow{2}{*}{ Small family businesses } & \multirow{2}{*}{ Mean } & \multirow{2}{*}{ Std dev. } & \multirow{2}{*}{ MCSE } & \multirow{2}{*}{ Median } & \multirow{2}{*}{\multicolumn{2}{|c|}{$\begin{array}{c}\text { Equal-tailed } \\
{[95 \% \text { cred. interval] }}\end{array}$}} & \multirow{2}{*}{$\begin{array}{c}\text { Prob. } \\
\text { Value }>0\end{array}$} \\
\hline & & & & & & & \\
\hline Staff recruitment and selection & 0.33 & 0.13 & 0.01 & 0.33 & 0.08 & 0.62 & 0.99 \\
\hline $\begin{array}{l}\text { Occupational training and } \\
\text { development }\end{array}$ & -0.19 & 0.12 & 0.02 & -0.19 & -0.42 & -0.04 & 0.05 \\
\hline Remuneration systems & 0.35 & 0.12 & 0.01 & 0.35 & 0.12 & 0.59 & 0.99 \\
\hline Age & -0.00 & 0.002 & 0.00 & -0.00 & -0.004 & 0.004 & 0.50 \\
\hline Exports & 0.02 & 0.04 & 0.006 & 0.02 & -0.08 & 0.11 & 0.64 \\
\hline Assets & 0.22 & 0.07 & 0.004 & 0.22 & 0.09 & 0.36 & 0.99 \\
\hline Constant & 0.81 & 0.34 & 0.09 & 0.82 & 0.17 & 1.40 & - \\
\hline Sigma2 & 0.57 & 0.08 & 0.002 & 0.56 & 0.43 & 0.75 & - \\
\hline \multicolumn{8}{|l|}{ Small non-family businesses } \\
\hline Staff recruitment and selection & 0.16 & 0.09 & 0.005 & 0.16 & -0.03 & 0.33 & 0.96 \\
\hline $\begin{array}{l}\text { Occupational training and } \\
\text { development }\end{array}$ & 0.04 & 0.10 & 0.01 & 0.04 & -0.17 & 0.24 & 0.66 \\
\hline Remuneration systems & 0.14 & 0.11 & 0.01 & 0.14 & -0.06 & 0.36 & 0.91 \\
\hline Age & 0.001 & 0.002 & 0.00 & 0.001 & 0.0001 & 0.14 & 0.69 \\
\hline Exports & 0.07 & 0.04 & 0.001 & 0.07 & 0.00 & 0.14 & 0.98 \\
\hline Assets & 0.16 & 0.05 & 0.004 & 0.16 & 0.06 & 0.27 & 0.99 \\
\hline Constant & 1.29 & 0.15 & 0.03 & 1.30 & 0.98 & 1.55 & - \\
\hline Sigma2 & 0.44 & 0.06 & 0.002 & 0.43 & 0.34 & 0.56 & - \\
\hline
\end{tabular}

HRM practices in SFBs and the age and size of the company

To study the evolution of HRM practices in SFBs with the age and size of the company, three Bayesian regressions were carried out, one for each HRM practice (dependent variables). The independent variables are age, assets, and exports. Table III presents the results of these regressions and the significance of each variable. 
Table III

Bayesian regression for $\mathrm{FBs}$, HRM practices

Regressão bayesiana para FBs, práticas de GRH

\begin{tabular}{|c|c|c|c|c|c|c|c|}
\hline & Mean & Std dev. & MCSE & Median & \multicolumn{2}{|c|}{$\begin{array}{c}\text { Equal-tailed } \\
{[95 \% \text { cred. interval] }}\end{array}$} & $\begin{array}{c}\text { Prob. } \\
\text { value }>0\end{array}$ \\
\hline \multicolumn{8}{|c|}{ Recruitment and selection } \\
\hline Exports & 0.04 & 0.04 & 0.002 & 0.04 & -0.037 & 0.13 & 0.85 \\
\hline Assets & 0.41 & 0.19 & 0.01 & 0.41 & 0.03 & 0.77 & 0.95 \\
\hline Assets $^{\wedge} 2$ & -0.07 & 0.032 & 0.001 & -0.07 & -0.13 & -0.01 & 0.01 \\
\hline LogAge & 0.07 & 0.35 & 0.02 & 0.07 & -0.63 & 0.77 & 0.58 \\
\hline $\operatorname{LogAge}^{\wedge} 2$ & -0.004 & 0.05 & 0.003 & -0.005 & -0.11 & 0.10 & 0.46 \\
\hline Constant & 2.01 & 0.58 & 0.03 & 1.99 & 0.91 & 3.17 & - \\
\hline sigma2 & 0.49 & 0.07 & 0.002 & 0.49 & 0.38 & 0.65 & - \\
\hline \multicolumn{8}{|c|}{ Training and development } \\
\hline Exports & -0.02 & 0.04 & 0.003 & -0.02 & -0.11 & 0.06 & 0.29 \\
\hline Assets & 0.43 & 0.18 & 0.02 & 0.43 & 0.07 & 0.80 & 0.99 \\
\hline Assets $^{\wedge} 2$ & -0.07 & 0.03 & 0.003 & -0.07 & -0.13 & -0.007 & 0.01 \\
\hline Age & -0.08 & 0.35 & 0.06 & -0.08 & -0.76 & 0.59 & 0.40 \\
\hline $\mathrm{Age}^{\wedge} 2$ & 0.003 & 0.05 & 0.009 & 0.003 & -0.10 & 0.11 & 0.53 \\
\hline Constant & 2.78 & 0.56 & 0.14 & 2.74 & 1.78 & 3.88 & - \\
\hline sigma & 0.49 & 0.07 & 0.002 & 0.49 & 0.37 & 0.66 & - \\
\hline \multicolumn{8}{|c|}{ Remuneration Systems } \\
\hline Exports & 0.01 & 0.04 & 0.002 & 0.01 & -0.07 & 0.09 & 0.64 \\
\hline Assets & 0.48 & 0.19 & 0.01 & 0.48 & 0.12 & 0.86 & 0.99 \\
\hline Assets`2 & -0.09 & 0.03 & 0.001 & -0.09 & -0.15 & -0.03 & 0.002 \\
\hline Age & -0.09 & 0.35 & 0.04 & -0.10 & -0.76 & 0.57 & 0.39 \\
\hline $\mathrm{Age}^{\wedge} 2$ & 0.03 & 0.05 & 0.006 & 0.03 & -0.08 & 0.13 & 0.70 \\
\hline Constant & 2.38 & 0.58 & 0.09 & 241.77 & 1.24 & 3.46 & - \\
\hline sigma2 & 0.51 & 0.07 & 0.001 & 0.50 & 0.39 & 0.66 & - \\
\hline
\end{tabular}

With regard to the age of the company, it can be observed that there is neither a linear nor a quadratic relationship between age (measured as its logarithm) and HRM practices. Therefore, $\mathrm{H} 3$ is rejected. The results found on the lack of relationship between the age of the company and its HRM practices confirm the lack of consensus from previous studies on the relationship between efficiency and age of the company (Guo et al., 2011). While some authors believe that with age comes efficiency and improvement in business practices (Cucculelli et al., 2014), other studies argue that young companies are the ones more prone to introducing management improvements (Poutziouris et al., 2015). In terms of size (measured by the volume of assets), the statistical values reveal two elements: 1) HRM practices increase with the size of the company, and 2) a linear relationship does not exist, but rather a quadratic one, with a negative coefficient. This means that there is an inverted U-shaped relationship, where SFBs would increase their practices as they become larger; however, this increase would begin to decrease at a certain size. In other words, HRM practices are smaller in smaller or larger SFBs, and therefore H4 would be partially accepted. The increase in HRM practices with the size of the company has already been highlighted by Rauch and Hatak (2016). However, the results of the present work show that 
this growth is not linear but quadratic, presenting an inverted $U$ shape, meaning that as a company reaches a certain size, a decrease will occur in the use of the studied HRM practices. The possibility of a decrease in HRM practices with size, without defining an inverted $U$ relationship, has been pointed out by Bayo-Moriones and Merino-Díaz (2001) and attributed to an increase in the bureaucratization of the company.

\section{CONCLUSIONS}

Despite the importance of people in the development of the human and social capital of FBs, the management of people in FBs has hardly been studied (Pittino et al., 2016), and few studies have investigated small businesses (fewer than 50 employees), as these types of companies are often voluntarily forgotten because of the argument that no HRM practices exist in such small companies. To fill this knowledge gap and expand the existing studies, three of the most relevant HRM practices (Pittino et al., 2016; Sánchez-Marín et al., 2017; Steijvers et al., 2017) were analysed: recruitment and selection, training and development, and remuneration. We focused our study on the Spanish wine sector, as this is one of the sectors most related to SFBs because of the structure of the industry, as well as for the links that exist among culture, tradition, prestige, and the name of the family (Gallucci et al., 2015).

Hypotheses have been divided into four groups. The first group (H1a, H1b, and H1c) suggests that SFBs use HRM practices to a lesser extent than SNFBs. These hypotheses have been tested using the MannWhitney U test for independent and non-parametric samples. The results show that SFBs occupy a worse position compared to SNFBs, but only in the case of the use of recruitment and selection practices. This circumstance had already been pointed out by previous research (Dyer, 2006; Gómez-Mejía et al., 2011; De Massis et al., 2015) and reveals how nepotism thwarts the selection of the most adequate people for the job in SFBs, which might jeopardize performance, as shown in Hypothesis 2.

Hypothesis 2 analyses the relation between HRM practices and performance. The results indicate that 'recruitment and selection' and 'remuneration' are clearly related to performance, whereas 'training and development' is not. The positive signs of recruitment and selection, which form the most relevant HRM practice, as well as of remuneration, are in line with most of the studies conducted since Astrachan and Kolenko (1994) and are not incompatible with other studies that consider a lower level of this practice in FBs (Hypothesis 1). The combination of the results found in the analysis of Hypotheses 1 and 2 make it evident that the fact that FBs conduct fewer recruitment and selection practices is an element which makes the development and achievement of their managementbased objectives difficult related to performance. Nepotism in FBs favours family members in recruitment and selection, making it difficult to recruit human resources outside the family (GómezMejía et al., 2011; Carrasco-Hernández and Sánchez-Marín, 2014).

It is important to remember that, according to the resource-based view (RBV) (Barney, 1991), to facilitate a competitive advantage, resources must be scarce and valuable, as well as difficult to imitate and substitute. As a result, HRM practices in SFBs could facilitate a competitive advantage because they are scarce and barely used - less than in SNFBs - which, combined with 'familiness', can provide companies with a collection of resources and key capabilities. Regarding SNFBs, the relationship between HRM practices and company performance is slightly less important, with recruitment and selection being the most important element, followed by remuneration. The practice of training and development does not seem to have a relationship with performance, although it does not present a negative value in this case.

Hypotheses 3 and 4 analyse the relationship between the size and age of the company and HRM practices. The study has shown that there is no relationship with age (Hypothesis 3), but there is a relationship with size (Hypothesis 4). As the company increases in size, it presents a higher level of HRM practices, but its relationship is not linear, but rather an inverted $\mathrm{U}$, that is, the level of HRM decreases at larger sizes. According to these results, it can be stated that there are several implications that can be taken into account by SFB managers. Recruitment and selection are not appropriately conducted in SFBs, and this is a reason for losing the best people in the best place, so that managers should begin using appropriate recruitment and selection practices to be able to place the best people in the different jobs of the company. On the other hand, the study shows how the companies, when growing, exceed their point of efficiency in HR management. This result should help managers to review and encourage greater worker participation in the management of the company; without this, an increase in the size of the entity produces disaffection and a feeling of bureaucratic helplessness. At the same time, the study opens the possibility for new analyses to be performed regarding the relationships 
among HRM practices, companies' results, and the way in which these evolve with age.

\section{ACKNOWLEDGMENTS}

The authors thank two anonymous reviewers and the editor for their helpful suggestions and comments. All remaining shortcomings are our sole responsibility. Silvia Abella-Garcés is also grateful for the support provided by the COMPETE [S52_20R] research group (Government of Aragón -Spain- and FEDER 2020-2022 ‘Construyendo Europa desde Aragón’).

\section{REFERENCES}

Aldrich H., Auster E.R., 1986. Even dwarfs started small: Liabilities of age and size and their strategic implications. Res. Organ. Behav., 8, 165-198.

Anderson R.C., Reeb D.M., 2003. Founding-family ownership and firm performance: Evidence from the S\&P 500. J. Financ., 58, 1301-1328.

Ashenfelter O., Storchmann K., 2016. The economics of wine, weather, and climate change. Rev. Env. Econ. Policy, 10, 25-46.

Astrachan J.H., Kolenko T.A., 1994. A neglected factor explaining family business success: Human resource practices. Fam. Bus. Rev., 7, 251-262.

Bardaji I., Iraizoz B., 2015. Uneven responses to climate and market influencing the geography of high-quality wine production in Europe. Reg. Environ. Change, 15, 79-92.

Barnett T., Kellermanns F.W., 2006. Are we family and are we treated as family? Nonfamily employees' perceptions of justice in the family firm. Entrep. Theory Pract., 30, 837-854.

Barney J., 1991. Firm resources and sustained competitive advantage. J. Manage., 17, 99-120.

Baruch Y., Holtom B.C., 2008. Survey response rate levels and trends in organizational research. Hum. Relat., 61, 1139-1160.

Bayo-Moriones J.A., Merino-Díaz de Cerio J., 2001. Size and HRM in the Spanish manufacturing industry. Empl. Relat., 23, 188207.

Besanko D., Dranove D., Shanley M., Schaefer S., 2009. Economics of strategy. 606 p. John Wiley \& Sons, New Jersey.

Boxall P., 1996. The strategic HRM debate and the resourcebased view of the firm. Hum. Resour. Manag. J., 6, 59-75.

Boxall P., 2013. Mutuality in the management of human resources: Assessing the quality of alignment in employment relationships. Hum. Resour. Manag. J., 23, 3-17.

Brandenburger A.M., Stuart H.W., 1996. Value-based business strategy. J. Econ. Manage. Strat., 5, 5-24.

Bresciani S., Giacosa E., Broccardo L., Culasso F., 2016. The family variable in the French and Italian wine sector. EuroMed $J$. Bus., 11, 101-118.

Cardon M.S., Stevens C.E., 2004. Managing human resources in small organizations: What do we know? Hum. Resour. Manage. R., 14, 295-323.

Carrasco-Hernandez A., Sánchez-Marín G., 2007. The determinants of employee compensation in family firms: Empirical evidence. Fam. Bus. Rev., 20, 215-228.
Carrasco-Hernández A.J., Sánchez-Marín G., 2014. El capital humano en la empresa familiar: un análisis exploratorio en empresas españolas. FAEDPYME Int. Rev.-FIR, 3, 19-29.

Chaney T., 2008. Distorted gravity: The intensive and extensive margins of international trade. Am. Econ. Rev., 98, 1707-1721.

Cosh A., Duncan J., Hughes A., Britain G., 1998. Investment in training and small firm growth and survival: An empirical analysis for the UK 1987-95. 73 p. Department for Education and Employment, London.

Cucculelli M., Mannarino L., Pupo V., Ricotta F., 2014. Ownermanagement, firm age, and productivity in Italian family firms. $J$. Small Bus. Manage., 52, 325-343.

Dawson A., 2012. Human capital in family businesses: Focusing on the individual level. J. Fam. Bus. Strateg., 3, 3-11.

De Kok J.M., Uhlaner L.M., Thurik A.R., 2006. Professional HRM practices in family owned-managed enterprises. J. Small Bus. Manage., 44, 441-460.

De Massis A., Frattini F., Pizzurno E., Cassia L., 2015. Product innovation in family versus nonfamily firms: An exploratory analysis. J. Small Bus. Manage., 53, 1-36.

Dess G.G., Davis P.S., 1984. Porter's (1985) generic strategies as determinants of strategic group membership and organizational performance. Acad. Manag. J., 27, 467-488.

Dyer W.G., 2006. Examining the "family effect" on firm performance. Fam. Bus. Rev., 19, 253-273.

Eurostat, 2019. Database. Available at: https://ec.europa.eu/eurostat/data/database (accessed 15.04.2020).

Fernández E., Pinilla V., 2018. Spain. In: Wine globalization: A new comparative history. 208-238. Anderson K., Pinilla V. (eds), Cambridge University Press, New York.

Ferrer-Lorenzo J.R., 2018. Factores de competitividad del sector vitivinícola español, 289 p. PhD Thesis, University of Zaragoza.

Ferrer-Lorenzo J.R., Maza-Rubio M.T., Abella-Garcés S., 2018. The competitive advantage in business, capabilities and strategy. What general performance factors are found in the Spanish wine industry? Wine Econ. Policy, 7, 94-108.

Ferrer-Lorenzo J.R., Maza-Rubio M.T., Abella-Garcés S., 2019. Business model and performance in the Spanish wine industry. $J$. Wine Res., 30, 31-47.

Franks J., Mayer C., Volpin P., Wagner H.F., 2011. The life cycle of family ownership: International evidence. Rev. Financ. Stud., 25, $1675-1712$.

Gallucci C., Santulli R., Calabrò A., 2015. Does family involvement foster or hinder firm performance? The missing role of family-based branding strategies. J. Fam. Bus. Strateg., 6, $155-$ 165 .

García-Cortijo, M.C., Villanueva, E.C., Castillo-Valero, J.S., Li, Y., 2019. Wine consumption in China: Profiling the 21st Century Chinese wine consumer. Ciência e Téc. Vitiv., 34, 71-83.

Gerhart B., Milkovich G.T., 1992. Employee compensation: Research and practice. In: Handbook of industrial and organizational Psychology. 481-569. Dunnette M.D., Hough L.M. (eds.), Consulting Psychologists Press, Palo Alto.

Gnan L., Lambrechts F., 2018. Human resources and mutual gains in family firms. J. Fam. Bus. Strateg., 9, I-II.

Gómez-Mejía L.R., Cruz C., Berrone P., De Castro J., 2011. The bind that ties: Socioemotional wealth preservation in family firms. Acad. Manag. Ann., 5, 653-707. 
Gómez-Mejía L.R, Haynes K.T., Núñez-Nickel M., Jacobson K.J., Moyano-Fuentes J., 2007. Socioemotional wealth and business risks in family-controlled firms: Evidence from Spanish olive oil mills. Admin. Sci. Quart., 52, 106-137.

Gómez-Mejía L.R., Larraza-Kintana M., Makri M., 2003. The determinants of executive compensation in family-controlled public corporations. Acad. Manage. J., 46, 226-237.

González M., Guzmán A., Pombo C., Trujillo M.A., 2012. Family firms and financial performance: The cost of growing. Emerg. Mark. Rev., 13, 626-649.

Guo C., Brown W.A., Ashcraft R.F., Yoshioka C.F., Dong H.K.D., 2011. Strategic human resources management in nonprofit organizations. Rev. Public Pers. Adm., 31, 248-269.

Habbershon T.G., Williams M.L., 1999. A resource-based framework for assessing the strategic advantages of family firms. Fam. Bus. Rev., 12, 1-25.

IEF, 2019. La empresa familiar en cifras. Available at: http://www.iefamiliar.com/cifras/1 (accessed 02.05.2020).

INE, 2018. Estadística estructural de empresas: sector industrial 2015. Available

http://www.ine.es/dyngs/INEbase/es/operacion.htm?c=Estadistica $\mathrm{C} \& \mathrm{cid}=1254736143952 \& \mathrm{menu}=$ resultados $\& \mathrm{idp}=1254735576715$ (accessed 14.05 2020)

Kidwell R.E., Fish A.J., 2007. High-performance human resource practices in Australian family businesses: Preliminary evidence from the wine industry. Int. Entrep. Manag. J., 3, 1-14.

Kotey B., Folker C., 2007. Employee training in SMEs: Effect of size and firm type - Family and nonfamily. J. Small Bus. Manage., 45, 214-238.

Kotlar J., De Massis A., Frattini F., Bianchi M., Fang H., 2013. Technology acquisition in family and nonfamily firms: A longitudinal analysis of Spanish manufacturing firms. J. Prod. Innovat. Manag., 30, 1073-1088.

León-Guerrero A.Y., McCann III J.E., Haley Jr J.D., 1998. A study of practice utilization in family businesses. Fam. Bus. Rev., 11, 107-120.

Lindow C.M., Stubner S., Wulf T., 2010. Strategic fit within family firms: The role of family influence and the effect on performance. J. Fam. Bus. Strateg., 1, 167-178.

López-Cabrales A., Pérez-Luño A., Cabrera R. ., 2009. Knowledge as a mediator between HRM practices and innovative activity. Hum. Resour. Manag., 48, 485-503.

Lozano-Reina G., Sánchez-Marín G., 2019. Prácticas de recursos humanos y rendimiento empresarial: explorando el modelo AMO en las PYME españolas. Small Bus. Int. Rev., 3, 67-85

Markman G.D., Baron R.A., 2003. Person-entrepreneurship fit: Why some people are more successful as entrepreneurs than others. Hum. Resour. Manage. R., 13, 281-301.

Martínez B., Requejo I., 2017. Does the type of family control affect the relationship between ownership structure and firm value? Int. Rev. Financ., 17, 135-146.

Maury B., 2006. Family ownership and firm performance: Empirical evidence from Western European corporations. J. Corp. Financ, 12, 321-341.

Mazzi C., 2011. Family business and financial performance: Current state of knowledge and future research challenges. $J$. Fam. Bus. Strateg., 2, 166-181.
Miller D., Le Breton-Miller I., Lester R.H., Cannella Jr A.A., 2007. Are family firms really superior performers? J. Corp. Financ., 13, 829-858.

Miralles-Marcelo J.L., del Mar Miralles-Quirós M., Lisboa I., 2014. The impact of family control on firm performance: Evidence from Portugal and Spain. J. Fam. Bus. Strateg., 5, 156168

OEMV, 2017. Principales tendencias de los mercados mundiales de vino. Available at: http://www.oemv.es/esp/-oemv.php (accessed 11.05.2020).

Ortega M.J., 2010. Competitive strategies and firm performance: Technological capabilities' moderating roles. J. Bus. Res., 63, 1273 1281.

Patel P.C., Cardon M.S., 2010. Adopting HRM practices and their effectiveness in small firms facing product-market competition. Hum. Resour. Manag., 49, 265-290.

Pittino D., Visintin F., Lenger T., Sternad D., 2016. Are high performance work practices really necessary in family SMEs? An analysis of the impact on employee retention. J. Fam. Bus. Strateg., 7, 75-89.

Poutziouris P., Savva C.S., Hadjielias E., 2015. Family involvement and firm performance: Evidence from UK listed firms. J. Fam. Bus. Strateg., 6, 14-32.

Rauch A., Hatak I., 2016. A meta-analysis of different HRenhancing practices and performance of small and medium sized firms. J. Bus. Venturing, 31, 485-504.

Reid R.S., Adams J.S., 2001. Human resource management - A survey of practices within family and non-family firms. J. Eur. Ind. Train., 25, 310-320.

Resco P., Iglesias A., Bardají I., Sotés V., 2016. Exploring adaptation choices for grapevine regions in Spain. Reg. Environ. Change, 16, 979-993.

Richard P.J., Devinney T.M., Yip G.S., Johnson G., 2009. Measuring organizational performance: Towards methodological best practice. J. Manage., 35, 718-804.

Rubio-Bañón A., Aragón A., 2008. Recursos estratégicos en la pymes. Revista Europea de Dirección y Economía de la Empresa, 17, 103-126.

SABI, 2017. Sistema de Analisis de Balances Ibericos. Available at: https://sabi.bvdinfo.com (accessed 14.05.2020).

Sánchez-Marín G., Meroño-Cerdán A.L., Carrasco-Hernández A.J., 2017. Formalized HR practices and firm performance: An empirical comparison of family and non-family firms. Int. J. Hum. Resour. Man., 30, 1084-1110.

Santos J.B., Brito L.A.L., 2012. Toward a subjective measurement model for firm performance. Braz. Adm. Rev., 9 (SPE), 95-117.

Schulze W.S., Gedajlovic E.R., 2010. Whither family business? $J$ Manage. Stud., 47, 191-204.

Sciascia S., Mazzola P., 2008. Family involvement in ownership and management: Exploring nonlinear effects on performance. Fam. Bus. Rev., 21, 331-345.

Serrano R., Fernández-Olmos M., Pinilla V., 2018. Internationalization and performance in agri-food firms. Span. J. Agric. Res., 16, e0107.

Sirmon D.G., Hitt M.A., 2003. Managing resources: Linking unique resources, management, and wealth creation in family firms. Entrep. Theory Pract., 27, 339-358. 
Soler I.P., Gemar G., Guerrero-Murillo R., 2017. Family and nonfamily business behaviour in the wine sector: A comparative study. Eur. J. Fam. Bus., 7, 65-73.

Spanos Y.E., Lioukas S., 2001. An examination into the causal logic of rent generation: Contrasting Porter's competitive strategy framework and the resource-based perspective. Strategic Manage. J., 22, 907-934.
Steijvers T., Lybaert N., Dekker J., 2017. Formal human resource practices in family firms. J. Fam. Bus. Manag., 7, 151-165.

Thach L., Kidwell R.E., 2009. HR practices in US and Australian family wineries: Cultural contrasts and performance impact. Int Entrep. Manag. J., 5, 219-240. 